\title{
Protein intake in early childhood and cardiometabolic health at school age: the Generation R Study
}

\author{
Trudy Voortman ${ }^{1,2}$ - Edith H. van den Hooven ${ }^{1,2} \cdot$ Myrte J. Tielemans, ${ }^{1,2}$. \\ Albert Hofman ${ }^{1} \cdot$ Jessica C$_{\text {C. Kiefte-de Jong }}{ }^{1}$. Vincent W. V. Jaddoe ${ }^{1,2,3}$. \\ Oscar H. Franco ${ }^{1}$
}

Received: 25 February 2015 / Accepted: 19 August 2015 / Published online: 2 September 2015 (C) The Author(s) 2015. This article is published with open access at Springerlink.com

\begin{abstract}
Purpose High protein intake in infancy has been linked to obesity. We aimed to examine the associations of protein intake in early childhood with cardiovascular and metabolic outcomes at school age.

Methods This study was performed in 2965 children participating in a population-based prospective cohort study. Protein intake at 1 year was assessed with a food frequency questionnaire and was adjusted for energy intake. At the children's age of 6 years, we measured their body fat percentage (BF\%), blood pressure (BP), and insulin, HDL cholesterol, and triglyceride serum levels. These measures were incorporated into a cardiometabolic risk factor score, using age- and sex-specific SD scores.

Results In covariate-adjusted models, higher protein intake was associated with a higher $\mathrm{BF} \%$, lower diastolic $\mathrm{BP}$, and lower triglyceride levels. We observed a significant interaction of protein intake with child sex on metabolic outcomes. Stratified analyses showed that protein intake was positively associated with BF\% [0.07 SD (95\% CI $0.02 ; 0.13$ ) per $10 \mathrm{~g} /$ day] and insulin levels in girls, but not in boys. In boys, but not in girls, higher protein intake was
\end{abstract}

Electronic supplementary material The online version of this article (doi:10.1007/s00394-015-1026-7) contains supplementary material, which is available to authorized users.

Trudy Voortman

trudy.voortman@erasmusmc.nl

1 Department of Epidemiology, Erasmus MC, University Medical Center, Rotterdam, The Netherlands

2 The Generation R Study Group, Erasmus MC, University Medical Center, Rotterdam, The Netherlands

3 Department of Pediatrics, Erasmus MC, University Medical Center, Rotterdam, The Netherlands associated with lower triglyceride levels $[-0.12$ SD (95\% $\mathrm{CI}-0.20 ;-0.04)$ per $10 \mathrm{~g} / \mathrm{day}]$ and a lower cardiometabolic risk factor score. Protein intake was not consistently associated with systolic BP or HDL cholesterol levels.

Conclusion Protein intake in early childhood was associated with a higher BF\% and higher insulin levels at 6 years in girls and with lower triglyceride levels in boys. Further studies are needed to explore these sex differences and to investigate whether the observed changes persist into adulthood.

Keywords Dietary protein $\cdot$ Children $\cdot$ Body fat $\cdot$ Blood pressure $\cdot$ Insulin $\cdot$ Epidemiology

\section{Introduction}

Already in childhood, adiposity, high blood pressure, dyslipidemia, and insulin resistance are highly prevalent [1]. These cardiometabolic risk factors in childhood have been shown to track to later life and are suggested to predict adult cardiovascular disease and type 2 diabetes [2, 3], highlighting the need to study determinants of cardiometabolic health already in early childhood [4].

Studies in adults suggest beneficial effects of high dietary protein intake on cardiometabolic risk factors, including a lower blood pressure, lower triglyceride levels, and a reduction in body weight [5-7]. Mechanisms underlying these effects remain to be elucidated, but may include increased satiety, increased energy expenditure, and metabolic effects of specific amino acids [8]. In contrast, a high protein intake in early childhood has been associated with a higher risk of obesity [9-12], suggesting that high protein intake in early life may lead to unfavorable effects on cardiometabolic health. A high protein intake in infancy 
may enhance the secretion of insulin-like growth factor 1 (IGF-1) and insulin [13, 14], which could in turn increase adipogenesis [15]. The period around the age of 1 year has been suggested to be a critical phase with respect to protein intake and later obesity risk, possibly because this period is often characterized by a transition from complementary feeding to family diet and a corresponding rapid increase in protein intake [16]. Thus far, studies investigating the effects of protein intake on insulin levels, blood lipids, and blood pressure in children are scarce and report inconsistent results [17].

We examined the associations of protein intake at the age of 1 year with body fat percentage, insulin levels, blood lipids, and a combined cardiometabolic risk factor score at the age of 6 years in 2965 children participating in a population-based prospective cohort study. In addition, we aimed to evaluate whether the associations differed for different sources of protein and whether associations differed by child sex, ethnicity, birth weight, or weight status at 6 years.

\section{Subjects and methods}

\section{Study population}

This study was embedded in the Generation R Study, a population-based prospective cohort study from fetal life onward in Rotterdam, the Netherlands [18]. All parents provided written informed consent, and 7893 children were available for follow-up studies in early childhood [18]. A questionnaire on child diet was implemented at a later stage of the study and was sent to 5088 mothers who provided consent for follow-up and had sufficient mastery of the Dutch language. In total, $3650(72 \%)$ of these mothers returned the questionnaire, of whom 3629 provided valid dietary data [19]. Of this group, 2965 single-born children visited the research center at the age of 6 years and had one or more cardiometabolic measurements available (Fig. 1). Not all children had information available on every outcome, mainly because some parents or children did not give consent for blood collection [20]. The number of children included in this study therefore differs per outcome, ranging from 1894 for the cardiometabolic score to 2911 for body fat measurements (Fig. 1).

\section{Dietary assessment}

Food intake was assessed at a median age of 12.9 months (95\% range 12.2-18.9) using a semiquantitative food frequency questionnaire (FFQ), covering the previous month [19]. This FFQ consisted of 211 food items that, according to a Dutch National Food Consumption Survey in 2002, are frequently consumed by children aged 9-18 months [21]. On the basis of standardized portion sizes and the Dutch Food Composition Table 2006 [22], food frequencies were converted into nutrient intakes. Evaluation of the FFQ against three 24-h recalls in a representative sample of 32 Dutch children with a median age of 14 months $(95 \%$ range 6-20) living in Rotterdam, showed an intraclass correlation coefficient of 0.7 for total protein intake $[19,23]$. Mothers of a subgroup of 899 Dutch children [18] received an additional FFQ around their child's age of 2 years (median 24.9 months, $95 \%$ range 24.3-27.6) [23]. Of these children, 714 had cardiometabolic measurements available at the age of 6 years.

\section{Cardiometabolic outcome assessments}

Children's cardiometabolic health outcomes were measured at their median age of 5.9 years (95\% range 5.6-6.6) in our research center by well-trained staff [20]. Weight was determined with a mechanical personal scale (SECA, Almere, the Netherlands), and height was measured with a Harpenden stadiometer (Holtain Limited, Dyfed, UK). Body fat mass was measured using a dual-energy X-ray absorptiometry (DXA) scanner (iDXA, GE-Lunar, 2008, Madison, WI, USA) using enCORE software version 13.6. Body fat percentage (BF\%) was calculated by expressing total fat mass as percentage of total body weight, and fat mass index (FMI) was calculated as total fat mass divided by height squared $\left(\mathrm{kg} / \mathrm{m}^{2}\right)$.

Non-fasting blood samples were obtained, transported, and stored as described in detail previously [20]. Serum concentrations of insulin, C-peptide, triglycerides, and total, HDL, and LDL cholesterol were measured at the Erasmus Medical Center with enzymatic methods (Cobas 8000, Roche, Almere, the Netherlands) [20]. Quality control samples demonstrated intra-assay coefficients of variation ranging from 0.77 to $1.17 \%$ and inter-assay coefficients ranging from 0.87 to $1.69 \%$.

While the children were lying, systolic (SBP) and diastolic blood pressure (DBP) were measured at the right brachial artery for four times with 1-min intervals, using the validated automatic sphygmomanometer Datascope Accutorr PlusTM (Paramus, NJ, USA). We used mean SBP and mean DBP of the last three measurements. For all cardiometabolic outcomes, we calculated age- and sex-specific SD scores (SDS), on the basis of the total Generation R Study population with data available on cardiometabolic health at 6 years ( $n$ ranging from 4414 to 6491) [18].

In line with previous studies that defined scores for a metabolic syndrome-like phenotype in children [24], we created a continuous score including five components: $\mathrm{BF} \%$, blood pressure, HDL cholesterol (HDL-C), triglycerides, and insulin levels [24]. The cardiometabolic score was 
Fig. 1 Flowchart of study participants included for the main analysis

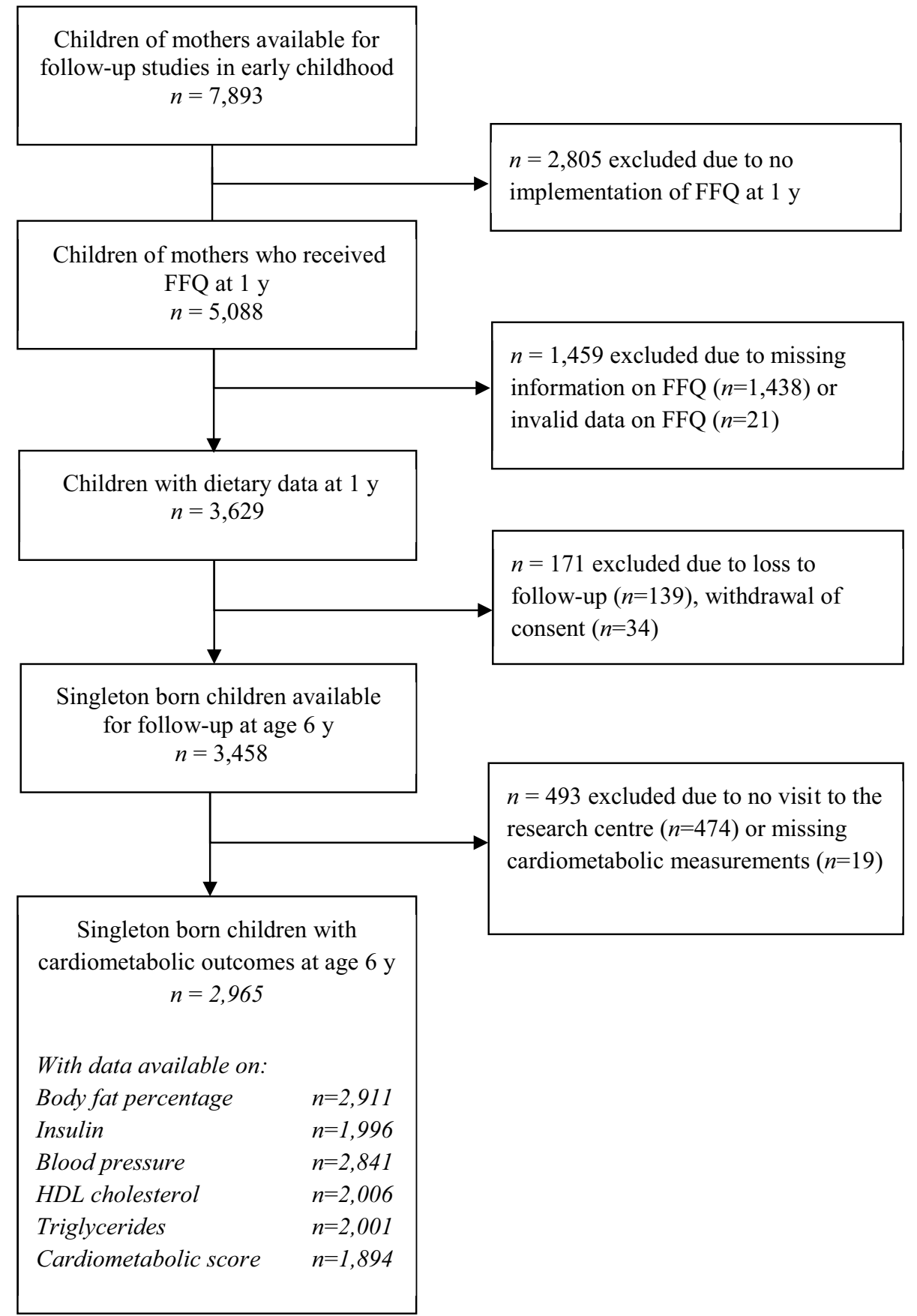

calculated as: $\mathrm{BF} \% \mathrm{SDS}+0.5 \times \mathrm{SBP} \mathrm{SDS}+0.5 \times \mathrm{DBP}$ $\mathrm{SDS}+$ triglycerides SDS $+(-1 \times \mathrm{HDL}-\mathrm{C} \mathrm{SDS})+$ insulin SDS, with a higher score reflecting higher cardiometabolic risk.

\section{Covariates}

Information on maternal age and educational level at enrollment was obtained with a questionnaire. Maternal height and weight were measured at our research center at enrollment in the study, and body mass index (BMI, kg/ $\mathrm{m}^{2}$ ) was calculated [18]. Maternal smoking during pregnancy was assessed using questionnaires in each trimester and was categorized into never; quit in the first trimester; or continued. Information on child's sex, birth weight, and gestational age was available from medical records and hospital registries, and gestational age- and sex-specific birth weight $Z$-scores were calculated [25]. Child's ethnicity was defined as Dutch when both parents were born in the Netherlands and as non-Dutch when one or both parents were born in another country [26]. Information on breastfeeding (never, partial, or exclusive in the first 
4 months) was obtained from delivery reports and postnatal questionnaires [19]. Child's height and weight around the age of 1 year were measured at the Community Child Health Centers, and age- and sex-specific BMI-SDS were calculated using Dutch reference curves [27]. Child fat and carbohydrate intake was derived from the FFQs and energy adjusted using the residual method [28]. Child BMI $\left(\mathrm{kg} / \mathrm{m}^{2}\right)$ at 6 years was calculated from measured height and weight and expressed in age- and sex-specific SDS [27]. Child weight status (underweight, normal weight, or overweight) was defined using international age- and sexspecific BMI cutoffs [29]. Screen time and participation in sports (yes/no) at the age of 6 years were assessed with a questionnaire as proxies for physical activity level during early childhood.

\section{Statistical analysis}

Because we were interested in the effect of protein independent of its energy content, we adjusted protein intake for total energy intake using the nutrient residual method [28]. To enhance interpretability, predicted protein intake for mean energy intake (1312 kcal/day) was added as constant. Protein intake was analyzed as continuous variable and categorized into tertiles. Insulin levels were squareroot-transformed to obtain a normal distribution, and subsequently, age- and sex-specific SDS were created for all outcomes.

We used linear regression models to assess the associations of total, animal, and vegetable protein intake at the age of 1 year with cardiometabolic outcomes at the age of 6 years. Animal and vegetable protein intakes were adjusted for each other. Potential confounders were selected based on theory or previous literature. The following covariates were included in the multivariable models based on theory: child's age, sex, ethnicity, birth weight $Z$-score, height for age, energy-adjusted fat intake, and total energy intake. Other potential confounders were entered individually in unadjusted models and were included in the final model only in case of a significant change $(\geq 10 \%)$ in the effect estimate of protein intake on at least one of the cardiometabolic outcomes [30]. Following this procedure, models were additionally adjusted for: maternal age, educational level, BMI, and smoking during pregnancy; and child's breastfeeding, age at dietary measurement, screen time, and participation in sports. The following covariates were considered but not included because they did not fulfill the $10 \%$ change criterion: household income, maternal parity, maternal alcohol consumption during pregnancy, child's gestational age at birth, timing of introduction of solid foods, and food allergies.

For all outcomes except $\mathrm{BF} \%$, we included $\mathrm{BF} \%$ at 6 years in a separate model to examine whether changes in body fat mediated the association with other cardiometabolic factors. To assess whether the associations between protein intake and cardiometabolic outcomes might differ by child sex, ethnicity, birth weight $Z$-score, or weight status at 6 years, we evaluated the statistical interaction by adding the product term of the potential effect modifier and total protein intake to the multivariable models.

We performed several sensitivity analyses. We additionally adjusted the multivariable models for child BMI-SDS at 1 year to assess whether protein intake at 1 year predicted childhood cardiometabolic health independent of baseline BMI. To examine whether associations with blood lipids, BP, or insulin levels could be explained by differences in body fat, we additionally adjusted these models for child BF\% at 6 years in separate models. We performed macronutrient substitution analyses in which we adjusted our models for carbohydrate intake or for saturated, monounsaturated, and polyunsaturated fat intake, instead of total fat intake, to check whether it made a difference whether protein was consumed at the expense of different other macronutrients. To explore whether associations with the cardiometabolic score were driven by one component only, we performed sensitivity analyses in which we excluded one component of the score at a time. Because the FFQ was developed and validated for Dutch children, we repeated the analyses in Dutch children only. To explore potential selection bias due to missing blood sampling, we examined descriptive statistics and associations of protein intake with body fat and blood pressure measurements in children who had blood samples available $(n=2010)$. In the subgroup of children with dietary data at 2 years, we assessed associations of protein intake at this age with cardiometabolic outcomes at 6 years using the same multivariable linear regression models as for protein intake at the age of 1 year.

Missing values of covariates were multiple imputed ( $n=10$ imputations) according to the fully conditional specification method (predictive mean matching) [31]. We report the pooled regression coefficients after the multiple imputation procedure. Statistical analyses were performed using SPSS Statistics version 21.0 (IBM Corp., Armonk, NY, USA).

\section{Results}

\section{Subject characteristics}

Characteristics of the children and their mothers are presented in Table 1. Mean $( \pm \mathrm{SD})$ total protein intake at the age of 1 year was $41.2 \mathrm{~g}( \pm 12.9)$, corresponding to $12.9 \%$ $( \pm 2.4)$ of total energy intake $(E \%)$. This is higher than recommended for this age group, but similar to intakes observed in the general Dutch and other Western pediatric 
Table 1 Characteristics of the participating children and their mothers

$$
\text { All }(n=2965)
$$

Boys $(n=1445)$

Girls $(n=1520)$

Maternal characteristics

Maternal age (year)

Maternal BMI at enrollment $\left(\mathrm{kg} / \mathrm{m}^{2}\right)$

$31.9(21.8-39.8)$

$31.9(21.7-40.0)$

$31.9(21.9-39.6)$

Education level (\%)

$23.7(19.0-35.2)$

$23.4(18.7-35.2)$

$23.6(19.0-36.0)$

\section{Primary}

Secondary

Higher

Smoking during pregnancy (\%)

Never

Until pregnancy was known

Continued

Child characteristics

Girls (\%)

Dutch ethnicity (\%)

Gestational age at birth (wk)

Birth weight ( $\mathrm{g}$ )

Breastfeeding (\%)

Exclusive in the first 4 months

Partial in the first 4 months

Never

5.2

36.3

58.5

78.1

10.3

11.6

51.3

68.8

$39.9(1.8)$

3452 (569)

31.4

60.7

7.9

Child characteristics at dietary measurement

Age at FFQ (mo)
Total energy intake (kcal/day)
Protein intake (g/day)
Total protein
Animal protein
Vegetable protein
Protein intake ( $E \%)$
Total protein
Animal protein
Vegetable protein

Child characteristics at 6-year visit

Age (year)

Screen time (h/day)

Participation in sports (\%)

Height (cm)

Weight $(\mathrm{kg})$

BMI $\left(\mathrm{kg} / \mathrm{m}^{2}\right)$

Body fat percentage (\%)

Systolic blood pressure $(\mathrm{mmHg})$

Diastolic blood pressure $(\mathrm{mmHg})$

HDL cholesterol (mmol/L)

Triglyceride levels $(\mathrm{mmol} / \mathrm{L})$

Insulin levels (pmol/L)
$12.9(12.2-18.9)$

1265 (678-2206)

$41.8(12.6)$

$25.6(10.2)$

$14.2(5.6)$

12.9 (2.4)

8.1 (2.4)

4.7 (1.4)

$5.9(5.7-6.6)$

$1.3(0.3-4.3)$

44.2

$118.2(5.2)$

$22.4(3.4)$

16.0 (1.6)

$23.5(16.2-36.4)$

$102(8)$

60 (7)

$1.35(0.31)$

$0.97(0.40-2.36)$

115 (18-398)
5.2

34.9

59.9

78.3

8.9

12.8

$-$

69.5

$39.9(1.8)$

3524 (576)

31.8

60.6

7.6

$12.9(12.2-19.1)$

1316 (691-2210)

$42.9(13.0)$

26.9 (10.5)

$15.5(5.5)$

$12.9(2.4)$

$8.1(2.4)$

$4.7(1.3)$

$5.9(5.6-6.6)$

$1.3(0.3-4.8)$

43.0

118.5 (5.1)

$22.5(3.4)$

$16.0(1.6)$

$21.1(15.7-33.5)$

$101(8)$

60 (7)

$1.36(0.31)$

$0.96(0.38-2.34)$

119 (17-382)
5.1

37.6

57.3

78.6

10.9

10.5

$-$

68.4

40.1 (1.8)

3383 (555)

31.0

60.9

8.1

$12.9(12.2-18.8)$

1221 (652-2230)

40.6 (12.2)

$25.7(9.8)$

14.4 (5.7)

12.9 (2.4)

$8.2(2.4)$

$4.6(1.5)$

$5.9(5.6-6.5)$

$1.2(0.2-4.6)$

45.5

117.9 (5.2)

$21.7(3.4)$

$16.0(1.7)$

$25.6(18.8-37.5)$

$102(8)$

61 (6)

1.33 (0.30)

0.98 (0.44-2.47)

115 (19-432)

Values are percentages for categorical variables, means (SD) for continuous variables with a normal distribution, or medians ( $95 \%$ range) for continuous variables with a skewed distribution

$E \%$ energy percentage, $F F Q$ food frequency questionnaire 
populations [32, 33]. Boys had a higher total energy and absolute protein intake than girls, but $E \%$ from protein was not different. Energy-adjusted protein intake was also similar among children with and without blood samples (Supplemental Table S1).

\section{Associations between total protein intake and cardiometabolic outcomes}

After adjustment for covariates, children with a protein intake in the highest tertile had a 0.08 SD $(95 \%$ CI 0.01 ; $0.16)$ higher BF\%, $0.14 \mathrm{SD}(95 \% \mathrm{CI}-0.24 ;-0.03)$ lower triglyceride levels, and a 0.09 SD $(95 \% \mathrm{CI}-0.18 ; 0.00)$ lower DBP than children in the lowest tertile of protein intake (Table 2). Protein intake was not significantly associated with SBP, insulin, HDL-C, or the cardiometabolic score.

Because we observed significant or borderline significant interactions between total protein intake and sex on $\mathrm{BF} \%(p=0.05)$, insulin $(p=0.01), \mathrm{C}$-peptide $(p=0.03)$, HDL-C $(p=0.08)$, triglycerides $(p<0.01)$, and the cardiometabolic score $(p=0.07)$, we also performed all analyses in boy and girls separately (Table 2). These stratified analyses revealed that higher protein intake was associated with a higher BF\% and higher insulin levels in girls, but not in boys. In contrast, higher protein intake was associated with lower triglyceride levels in boys, but not in girls. The association between protein intake and DBP was slightly stronger in boys than in girls, but in both groups, effect estimates were similar to those observed in the whole population. Finally, protein intake was not associated with the cardiometabolic score in girls, while in boys, higher intake was associated with a lower cardiometabolic risk factor score $[-0.56 \mathrm{SD}(95 \% \mathrm{CI}-0.92 ;-0.20)$ per $10 \mathrm{~g} /$ day of total protein intake].

Additional adjustment for BMI at 1 year (data not shown) or BF\% at 6 years (Supplemental Table S2) did not change the results. Associations of protein intake with C-peptide levels were similar to those observed with insulin levels, results for FMI were similar to those observed for $\mathrm{BF} \%$, and no associations were observed with total or LDL cholesterol (Supplemental Table S3). Results from unadjusted models were similar to those from the adjusted models, with similar differences between boys and girls (Supplemental Table S4).

\section{Additional analyses}

The association between protein intake and $\mathrm{BF} \%$ in girls was mainly driven by animal protein intake, whereas effect estimates for other outcomes were similar for animal and vegetable protein intake (Supplemental Table S5). Associations between protein intake and cardiometabolic outcomes did not significantly differ by the children's ethnicity, weight status at 6 years, or birth weight $Z$-score. Adjusting the models for total carbohydrate or different fatty acids instead of total fat intake rendered similar results for protein intake (data not shown). Sensitivity analyses in Dutch children only $(n=1965)$ showed similar effect estimates as compared to the whole group, except for DBP for which the effect estimates were slightly larger in Dutch children (Supplemental Table S6). Sensitivity analyses restricted to children with blood sample available rendered similar effect estimates for body fat and blood pressure (data not shown). Analyses in which we excluded one component from the cardiometabolic score at a time revealed similar associations. In the subgroup of children with dietary data at age 2 years $(n=714)$, protein intake at the age of 2 years was no longer associated with BF\% or insulin levels at 6 years in girls, while in boys, it was associated with a lower BF\% (Supplemental Table S7). Associations between protein intake at age 2 years and other cardiometabolic outcomes were similar to those observed for protein intake at age 1 year, but with wider confidence intervals.

\section{Discussion}

This large prospective population-based study suggests that protein intake at the age of 1 year is associated with cardiometabolic health at school age, but that these associations differ by sex. A higher protein intake was associated with a higher $\mathrm{BF} \%$ and higher insulin levels in girls and with lower triglyceride levels, lower DBP, and a lower cardiometabolic risk factor score in boys. Protein intake was not consistently associated with SBP or HDL cholesterol levels at the age of 6 years. The associations with BP, insulin, and triglyceride levels were independent of $\mathrm{BF} \%$. Although the effect estimates were small and may not have direct consequences on an individual level, they remained statistically significant after adjustment for several confounders and may be relevant on a population level in predicting later cardiometabolic disease risk [2,3].

\section{Interpretation and comparison with previous studies}

The association between protein intake in early life and later obesity is in line with results from a large European trial in 1090 infants. In this study, children who received high-protein formula in infancy had a higher BMI at 6 years than children who received lower-protein formula [12]. However, only a few previous studies examined associations between protein intake in the first years of life and later measures of body fat. Two observational studies reported no association between early-life protein intake and $\mathrm{BF} \%$ at the ages of 4 or 10 years $[34,35]$, whereas two 


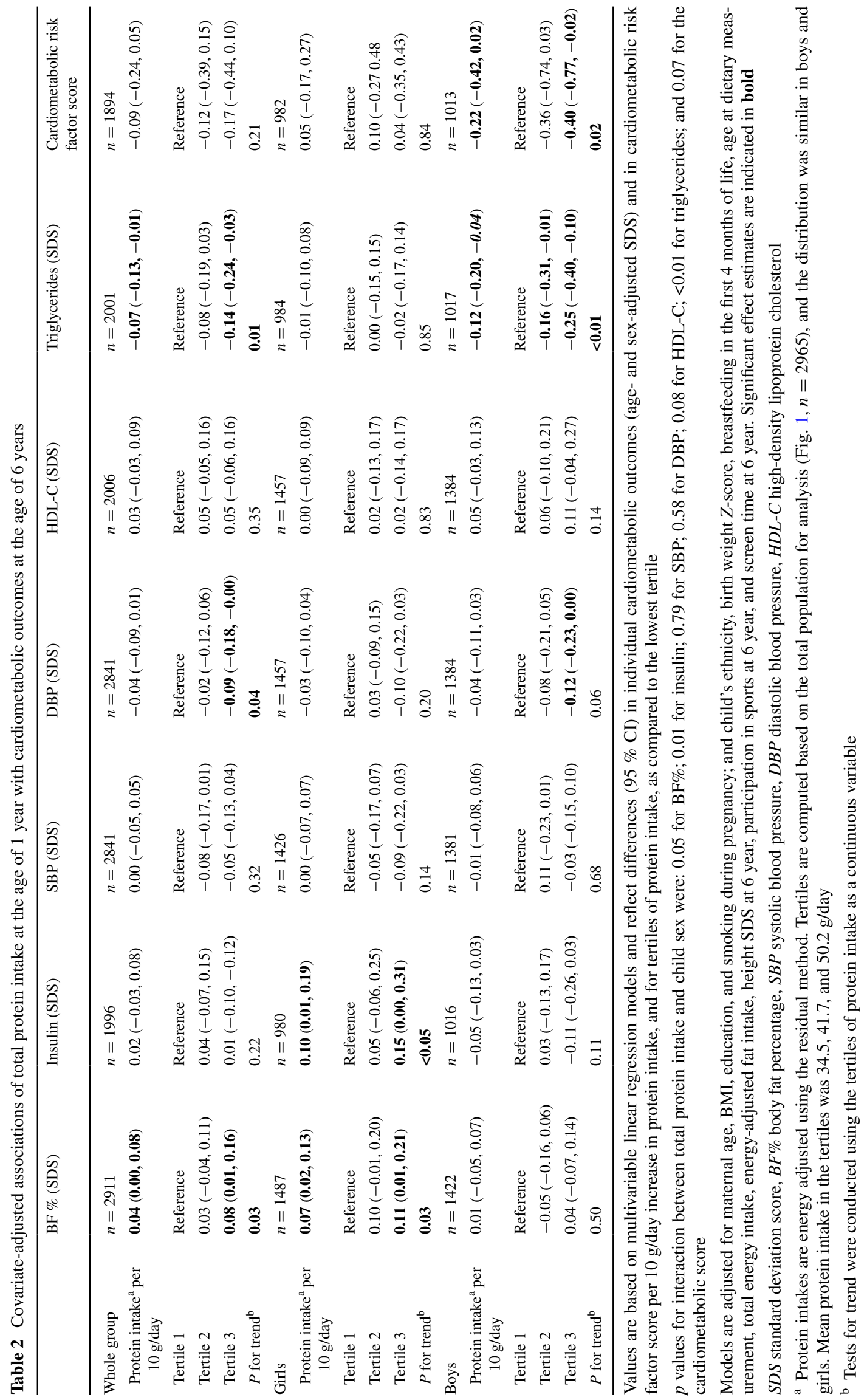


other studies reported positive associations with skinfold thicknesses at 7 or 8 years $[9,10]$.

Nevertheless, none of these studies reported differences between boys and girls. The observed differences between boys and girls in our study might be explained by a difference in timing of adiposity rebound (AR) or in peak BMI at $\mathrm{AR}$. The AR corresponds to a rise in BMI curve followed by a rise in fat mass index that occurs between the age of 5 and 7 years $[36,37]$ and tends to occur earlier in girls than in boys [38]. A previous study reported that higher protein intake in early childhood is associated with an earlier AR [10], whereas in other studies, no consistent relation was observed with timing of $\operatorname{AR}[39,40]$. One of these latter studies, however, did observe that a higher protein intake in early childhood was associated with a higher BMI at AR in girls, but not in boys [40].

Another potential mechanism for the observed differences between boys and girls is a difference in endocrine response to high protein intake [41]. High protein intake has been associated with increased IGF-1 secretion, which may mediate the relation between protein intake and obesity [41]. In the previously mentioned European trial with high- and low-protein infant formulas, although no sex differences were observed in the association between the intervention and growth [12], girls had a stronger IGF-1 response to the higher protein formula than boys [41]. In line with these findings, we observed clear sex differences in the association between protein intake and insulin levels, which also acts as a growth hormone [41]. Protein intake was strongly associated with higher insulin levels in girls, but not at all in boys. When we adjusted the BF\% models in girls for insulin levels, the association between protein intake and BF\% was attenuated, which suggests that insulin might mediate the association with BF\%. Studies in adults show that dietary proteins stimulate the secretion of insulin [42], and high protein intake has been related to an increased risk of type 2 diabetes [43]. However, previous studies in children did not report effects of high protein intake on measures of insulin sensitivity $[17,44,45]$.

We observed that higher protein intake was associated with a lower DBP, but not consistently with SBP. A previous study reported inverse associations between protein intake and both SBP and DBP in 2.5-year-old children [46], while two other studies observed no associations $[47,48]$. In line with our findings, a large observational study in 1605 adolescents (12.5-17.5 years) showed an inverse association between protein intake and DBP, but not SBP in boys [49]. Several meta-analyses of studies in adults also report inverse associations between protein intake and blood pressure [5-7]. The mechanisms underlying a beneficial effect of protein intake on blood pressure have not yet been clarified and may differ for intake of different amino acids [49]. Proposed pathways of a blood-pressure-lowering effect of protein include increased synthesis of ion channels; increased renal plasma flow; increased glomerular filtration rate; or vasodilating effects of certain amino acids [5, 7]. However, we have previously shown in our population that protein intake in early childhood is not associated with glomerular filtration rate [50].

The present study shows that protein intake was not associated with total, HDL or LDL cholesterol levels, but we did observe lower triglyceride levels in relation to higher protein intake in boys. These latter findings correspond to results from a previous study in adolescents, in which higher absolute protein intake was associated with lower triglyceride and cholesterol levels [45]. However, in this study, the association was no longer significant after adjustment for total energy intake. Other previous studies in children showed no association between protein intake and cholesterol or triglyceride levels (reviewed by [17]). However, in line with our results, a meta-analysis of trials in adults showed that subjects consuming a higher protein diet had lower triglyceride levels than subjects with a lower-protein diet [6]. Potential mechanisms of a direct effect of protein intake on lipid profile are unknown. A high carbohydrate diet, which could correspond to a lowprotein diet, has been shown to reduce triglyceride clearance and thereby increase serum levels of triglycerides [51]. In our analyses, however, effect estimates for protein intake were similar after adjusting for either carbohydrate or fat intake.

In our study, we observed differences in animal versus vegetable protein intake on the association with body fat, but not on the other cardiometabolic outcomes. In one previous study, it was also reported that animal, and more specifically, dairy protein, but not meat or cereal protein intake at 1 year was associated with child body fat at 7 years [16]. Animal and vegetable protein might have different effects on adiposity via differences in IGF-1: Another study reported that intake of animal, but not vegetable protein in 2.5-year-old children was associated with higher IGF-1 concentrations [15]. Studies in adults report inconsistent results for differences in effects of animal and vegetable protein on cardiometabolic diseases [43, 52]. Further studies, both in adult and in child populations, are needed to elucidate the effects of animal and vegetable protein on cardiometabolic health.

\section{Methodological considerations}

Important strengths of this study are its prospective population-based design and the large number of subjects being studied. Of all mothers who received the FFQ, $72 \%$ returned the questionnaire. These mothers were generally higher educated and had a more healthy lifestyle than mothers who did not return the FFQ [23]. Of all children 
of whom information was available on food intake, more than $80 \%$ participated in the follow-up measurements at 6 years. Blood samples were available in $67 \%$ of these children, who had on average higher educated mothers than children without blood samples, but were not different with regard to protein intake, body fat, or blood pressure (Supplemental Table S1). Furthermore, associations between protein intake and body fat or blood pressure were not different among the children with blood samples available than among the whole group.

The FFQ was sent to Dutch-speaking mothers only, but with different ethnic backgrounds. A limitation of our FFQ is that it was only validated for Dutch children [19]. However, sensitivity analyses restricted to Dutch children revealed similar results, suggesting that in our analyses, no large bias due to ethnicity was present. Strengths of our dietary assessment are that an FFQ measures habitual diet rather than dietary intake at just one or a few days, and that we calculated not only total protein intake, but also broken down in protein from animal and vegetable sources. A limitation is that we did not have dietary data at 6 years and therefore could not study whether the associations of early diet were independent of current diet. Because we adjusted our models for total energy and fat intake, the effect estimates can be interpreted as the effect of exchanging carbohydrate for a similar number of calories from protein. Adjusting the models for other macronutrients rendered similar results, suggesting that for cardiometabolic outcomes, it does not matter whether fat or carbohydrate is exchanged for protein in the diets of young children.

An important strength of our study is that we had information on many potential parental and child confounders for which we adjusted in our analyses. However, because of the observational design of our study, residual confounding of other lifestyle-related variables, such as physical activity, may still be present. We used screen time and participation in sports at the age of 6 years as proxies for physical activity during early childhood, but unfortunately, we had no information available on physical activity of the children at earlier ages.

Finally, we performed detailed measurements of childhood adiposity and cardiometabolic health. Because we evaluated multiple outcomes, this might have increased the risk of chance findings (type I errors) due to multiple testing. Nevertheless, because the cardiometabolic outcomes considered are correlated, we did not adjust for multiple comparisons. In addition, we combined the individual risk factors in a continuous cardiometabolic score. Advantages over a dichotomous metabolic syndrome definition are that a continuous score is less prone to error and more sensitive to pick up differences because more information is used [24].

\section{Conclusion}

In this prospective cohort study in young children with high protein intake, we observed differences in associations of protein intake with cardiometabolic outcomes between boys and girls. Protein intake in early childhood was associated with higher insulin levels and a higher BF\% at 6 years in girls and with lower triglyceride levels and a lower cardiometabolic risk factor score in boys. In both sexes, protein intake tended to be associated with a lower diastolic blood pressure. Further studies are needed to explore whether and how protein intake differently affects cardiometabolic health in boys and girls and to investigate whether the observed changes in cardiometabolic outcomes in childhood persist into adulthood.

Acknowledgments The Generation R Study is made possible by financial support from the Erasmus University Medical Center, Rotterdam; the Erasmus University, Rotterdam; the Dutch Ministry of Health, Welfare and Sport; the Netherlands Organization for Health Research and Development (ZonMw); and the Netherlands Organization for Scientific Research (NWO). VWVJ received an additional grant from the Netherlands Organization for Health Research and Development (ZonMW VIDI: 016.136.361). The authors TV, EHH, MJT, JCKJ, and OHF work in ErasmusAGE, funded by Nestlé Nutrition (Nestec Ltd.), Metagenics Inc., and AXA. The funders had no role in design or conduct of this study; collection, management, analysis, or interpretation of the data; or preparation, review, or approval of this manuscript. The authors gratefully acknowledge the contributions of children and parents, general practitioners, hospitals, and midwives involved in the Generation R Study.

\section{Compliance with ethical standards}

Conflict of interest The authors have no conflicts of interest relevant to this article to disclose.

Ethical standard The study was approved by the Medical Ethics Committee of Erasmus Medical Center, Rotterdam, and all parents provided written informed consent.

Open Access This article is distributed under the terms of the Creative Commons Attribution 4.0 International License (http://creativecommons.org/licenses/by/4.0/), which permits unrestricted use, distribution, and reproduction in any medium, provided you give appropriate credit to the original author(s) and the source, provide a link to the Creative Commons license, and indicate if changes were made.

\section{References}

1. Weiss R, Dziura J, Burgert TS, Tamborlane WV, Taksali SE, Yeckel CW, Allen K, Lopes M, Savoye M, Morrison J, Sherwin RS, Caprio S (2004) Obesity and the metabolic syndrome in children and adolescents. N Engl J Med 350(23):2362-2374. doi:10.1056/NEJMoa031049

2. Morrison JA, Friedman LA, Gray-McGuire C (2007) Metabolic syndrome in childhood predicts adult cardiovascular disease 25 years later: the Princeton Lipid Research Clinics Follow-up Study. Pediatrics 120(2):340-345. doi:10.1542/peds.2006-1699 
3. Morrison JA, Friedman LA, Wang P, Glueck CJ (2008) Metabolic syndrome in childhood predicts adult metabolic syndrome and type 2 diabetes mellitus 25 to 30 years later. J Pediatr 152(2):201-206. doi:10.1016/j.jpeds.2007.09.010

4. Felix JF, Voortman T, van den Hooven EH, Sajjad A, Leermakers ET, Tharner A, Kiefte-de Jong JC, Duijts L, Verhulst FC, de Jongste JC, Tiemeier H, Hofman A, Rivadeneira F, Moll HA, Raat H, Jaddoe VW, Franco OH (2014) Health in children: a conceptual framework for use in healthy ageing research. Maturitas 77(1):47-51. doi:10.1016/j.maturitas.2013.09.011

5. Altorf-van der Kuil W, Engberink MF, Brink EJ, van Baak MA, Bakker SJ, Navis G, van't Veer P, Geleijnse JM (2010) Dietary protein and blood pressure: a systematic review. PLOS ONE 5(8):e12102. doi:10.1371/journal.pone.0012102

6. Santesso N, Akl EA, Bianchi M, Mente A, Mustafa R, HeelsAnsdell D, Schunemann HJ (2012) Effects of higher- versus lower-protein diets on health outcomes: a systematic review and meta-analysis. Eur J Clin Nutr 66(7):780-788. doi:10.1038/ ejen.2012.37

7. Rebholz CM, Friedman EE, Powers LJ, Arroyave WD, He J, Kelly TN (2012) Dietary protein intake and blood pressure: a meta-analysis of randomized controlled trials. Am J Epidemiol 176(Suppl 7):S27-S43. doi:10.1093/aje/kws245

8. Westerterp-Plantenga MS, Lemmens SG, Westerterp KR (2012) Dietary protein-its role in satiety, energetics, weight loss and health. Br J Nutr 108(Suppl 2):S105-S112. doi:10.1017/ S0007114512002589

9. Gunther ALB, Buyken AE, Kroke A (2007) Protein intake during the period of complementary feeding and early childhood and the association with body mass index and percentage body fat at $7 \mathrm{y}$ of age. Am J Clin Nutr 85(6):1626-1633

10. Rolland-Cachera MF, Deheeger M, Akrout M, Bellisle F (1995) Influence of macronutrients on adiposity development: a follow up study of nutrition and growth from 10 months to 8 years of age. Int J Obes 19(8):573-578

11. Scaglioni S, Agostoni C, De Notaris R, Radaelli G, Radice N, Valenti M, Giovannini M, Riva E (2000) Early macronutrient intake and overweight at five years of age. Int J Obes 24(6):777781. doi:10.1038/sj.ijo.0801225

12. Weber M, Grote V, Closa-Monasterolo R, Escribano J, Langhendries JP, Dain E, Giovannini M, Verduci E, Gruszfeld D, Socha P, Koletzko B, European Childhood Obesity Trial Study Group (2014) Lower protein content in infant formula reduces BMI and obesity risk at school age: follow-up of a randomized trial. Am J Clin Nutr 99(5):1041-1051. doi:10.3945/ajcn.113.064071

13. Socha P, Grote V, Gruszfeld D, Janas R, Demmelmair H, ClosaMonasterolo R, Subias JE, Scaglioni S, Verduci E, Dain E, Langhendries JP, Perrin E, Koletzko B (2011) Milk protein intake, the metabolic-endocrine response, and growth in infancy: data from a randomized clinical trial. Am J Clin Nutr 94(6 Suppl):1776S1784S. doi:10.3945/ajen.110.000596

14. Canete R, Gil-Campos M, Aguilera CM, Gil A (2007) Development of insulin resistance and its relation to diet in the obese child. Eur J Nutr 46(4):181-187. doi:10.1007/ s00394-007-0648-9

15. Hoppe C, Udam TR, Lauritzen L, Molgaard C, Juul A, Michaelsen KF (2004) Animal protein intake, serum insulin-like growth factor I, and growth in healthy 2.5-y-old Danish children. Am J Clin Nutr 80(2):447-452

16. Gunther ALB, Remer T, Kroke A, Buyken AE (2007) Early protein intake and later obesity risk: which protein sources at which time points throughout infancy and childhood are important for body mass index and body fat percentage at $7 \mathrm{y}$ of age? Am $\mathrm{J}$ Clin Nutr 86(6): 1765-1772

17. Voortman T, Vitezova A, Bramer WM, Ars CL, Bautista PK, Buitrago-Lopez A, Felix JF, Leermakers ET, Sajjad A, Sedaghat
S, Tharner A, Franco OH, van den Hooven EH (2015) Effects of protein intake on blood pressure, insulin sensitivity and blood lipids in children: a systematic review. Br J Nutr 113(3):383402. doi:10.1017/S0007114514003699

18. Jaddoe VW, van Duijn CM, Franco OH, van der Heijden AJ, van Iizendoorn $\mathrm{MH}$, de Jongste JC, van der Lugt A, Mackenbach JP, Moll HA, Raat H, Rivadeneira F, Steegers EA, Tiemeier H, Uitterlinden AG, Verhulst FC, Hofman A (2012) The Generation R Study: design and cohort update 2012. Eur J Epidemiol 27(9):739-756. doi:10.1007/s10654-012-9735-1

19. Kiefte-de Jong JC, de Vries JH, Bleeker SE, Jaddoe VW, Hofman A, Raat H, Moll HA (2013) Socio-demographic and lifestyle determinants of 'Western-like' and 'Health conscious' dietary patterns in toddlers. Br J Nutr 109(1):137-147. doi:10.1017/ S0007114512000682

20. Kruithof CJ, Kooijman MN, van Duijn CM, Franco OH, de Jongste JC, Klaver CC, Mackenbach JP, Moll HA, Raat H, Rings EH, Rivadeneira F, Steegers EA, Tiemeier H, Uitterlinden AG, Verhulst FC, Wolvius EB, Hofman A, Jaddoe VW (2014) The Generation R Study: biobank update 2015. Eur J Epidemiol 29(12):911-927. doi:10.1007/s10654-014-9980-6

21. Hulshof KFAM, Breedveld BC (2002) Zo eten jonge peuters in Nederland. Voedingscentrum, TNO-Voeding

22. Netherlands Nutrition Centre (2006) Dutch Food Composition Database 2006 (NEVO-table 2006). Netherlands Nutrition Centre (Voedingscentrum), Den Haag

23. Voortman T, Kiefte-de Jong JC, Geelen A, Villamor E, Moll HA, de Jongste JC, Raat H, Hofman A, Jaddoe VW, Franco OH, van den Hooven EH (2015) The development of a diet quality score for preschool children and its validation and determinants in the Generation R Study. J Nutr 145(2):306-314. doi:10.3945/ jn.114.199349

24. Eisenmann JC (2008) On the use of a continuous metabolic syndrome score in pediatric research. Cardiovasc Diabetol 7:17. doi:10.1186/1475-2840-7-17

25. Niklasson A, Ericson A, Fryer JG, Karlberg J, Lawrence C, Karlberg P (1991) An update of the Swedish reference standards for weight, length and head circumference at birth for given gestational age (1977-1981). Acta Paediatr Scand 80(8-9):756-762

26. Statistics Netherlands (2004) Immigrants in the Netherlands 2004 (Allochtonen in Nederland 2004). Statistics Netherlands (Centraal Bureau voor de Statistiek), Den Haag/Heerlen

27. Fredriks AM, van Buuren S, Burgmeijer RJ, Meulmeester JF, Beuker RJ, Brugman E, Roede MJ, Verloove-Vanhorick SP, Wit JM (2000) Continuing positive secular growth change in The Netherlands 1955-1997. Pediatr Res 47(3):316-323

28. Willett WC, Howe GR, Kushi LH (1997) Adjustment for total energy intake in epidemiologic studies. Am J Clin Nutr 65(4 Suppl):1220S-1228S (discussion 1229S-1231S)

29. Cole TJ, Bellizzi MC, Flegal KM, Dietz WH (2000) Establishing a standard definition for child overweight and obesity worldwide: international survey. BMJ 320(7244):1240-1243

30. Mickey RM, Greenland S (1989) The impact of confounder selection criteria on effect estimation. Am J Epidemiol 129(1):125-137

31. Sterne JA, White IR, Carlin JB, Spratt M, Royston P, Kenward MG, Wood AM, Carpenter JR (2009) Multiple imputation for missing data in epidemiological and clinical research: potential and pitfalls. BMJ 338:b2393. doi:10.1136/bmj.b2393

32. Hornell A, Lagstrom H, Lande B, Thorsdottir I (2013) Protein intake from 0 to 18 years of age and its relation to health: a systematic literature review for the 5th Nordic Nutrition Recommendations. Food Nutr Res. doi:10.3402/fnr.v57i0.21083

33. Ocké MC, van Rossum CTM, Fransen HP, Buurma EJM, Boer EJd, Brants HAM, Niekerk EM, Laan JDvd, Drijvers JJMM, Ghameshlou Z (2008) Dutch National Food Consumption 
Survey-Young Children 2005/2006. National Institute for Public Health and the Environment (RIVM), Netherlands

34. Hoppe C, Molgaard C, Thomsen BL, Juul A, Michaelsen KF (2004) Protein intake at 9 mo of age is associated with body size but not with body fat in 10-y-old Danish children. Am J Clin Nutr 79(3):494-501

35. Robinson S, Crozier S, Marriott L, Harvey N, Inskip H, Godfrey $\mathrm{K}$, Cooper C (2008) Protein intake in infancy is not associated with adiposity at 4 years of age: findings from the Southampton Women's Survey. Proc Nutr Soc 67(OCE8):E347. doi:10.1017/ S0029665108000219

36. Rolland-Cachera MF, Deheeger M, Maillot M, Bellisle F (2006) Early adiposity rebound: causes and consequences for obesity in children and adults. Int J Obes (Lond) 30(Suppl 4):S11-S17. doi:10.1038/sj.ijo.0803514

37. Plachta-Danielzik S, Bosy-Westphal A, Kehden B, Gehrke MI, Kromeyer-Hauschild K, Grillenberger M, Willhoft C, Heymsfield SB, Muller MJ (2013) Adiposity rebound is misclassified by BMI rebound. Eur J Clin Nutr 67(9):984-989. doi:10.1038/ ejcn.2013.131

38. Boonpleng W, Park CG, Gallo AM (2012) Timing of adiposity rebound: a step toward preventing obesity. Pediatr Nurs 38(1):37-42

39. Dorosty AR, Emmett PM, Cowin IS, Reilly JJ (2000) Factors associated with early adiposity rebound. Pediatrics 105(5):1115-1118

40. Gunther ALB, Buyken AE, Kroke A (2006) The influence of habitual protein intake in early childhood on BMI and age at adiposity rebound: results from the DONALD Study. Int J Obes 30(7):1072-1079. doi:10.1038/sj.ijo.0803288

41. Closa-Monasterolo R, Ferre N, Luque V, Zaragoza-Jordana M, Grote V, Weber M, Koletzko B, Socha P, Gruszfeld D, Janas R, Xhonneux A, Dain E, Scaglioni S, Escribano J, Childhood Obesity Project Study Group (2011) Sex differences in the endocrine system in response to protein intake early in life. Am J Clin Nutr 94(6 Suppl):1920S-1927S. doi:10.3945/ajen.110.001123

42. Tremblay F, Lavigne C, Jacques H, Marette A (2007) Role of dietary proteins and amino acids in the pathogenesis of insulin resistance. Annu Rev Nutr 27:293-310. doi:10.1146/annurev. nutr.25.050304.092545

43. van Nielen M, Feskens EJ, Mensink M, Sluijs I, Molina E, Amiano P, Ardanaz E, Balkau B, Beulens JW, Boeing H, ClavelChapelon F, Fagherazzi G, Franks PW, Halkjaer J, Huerta JM, Katzke V, Key TJ, Khaw KT, Krogh V, Kuhn T, Menendez VV, Nilsson P, Overvad K, Palli D, Panico S, Rolandsson O, Romieu I, Sacerdote C, Sanchez MJ, Schulze MB, Spijkerman AM, Tjonneland A, Tumino R, van der AD, Wurtz AM, Zamora-Ros
R, Langenberg C, Sharp SJ, Forouhi NG, Riboli E, Wareham NJ, InterAct Consortium (2014) Dietary protein intake and incidence of type 2 diabetes in Europe: the EPIC-InterAct Case-Cohort Study. Diabetes Care 37(7):1854-1862. doi:10.2337/dc13-2627

44. Garnett SP, Gow M, Ho M, Baur LA, Noakes M, Woodhead HJ, Broderick CR, Burrell S, Chisholm K, Halim J, De S, Steinbeck K, Srinivasan S, Ambler GR, Kohn MR, Cowell CT (2013) Optimal macronutrient content of the diet for adolescents with prediabetes; RESIST a randomised control trial. J Clin Endocrinol Metab 98(5):2116-2125. doi:10.1210/jc.2012-4251

45. Lin Y, Mouratidou T, Vereecken C, Kersting M, Bolca S, de Moraes AC, Cuenca-Garcia M, Moreno LA, Gonzalez-Gross M, Valtuena J, Labayen I, Grammatikaki E, Hallstrom L, Leclercq C, Ferrari M, Gottrand F, Beghin L, Manios Y, Ottevaere C, Van Oyen H, Molnar D, Kafatos A, Widhalm K, Gomez-Martinez S, Prieto LE, De Henauw S, Huybrechts I, Group Hs (2015) Dietary animal and plant protein intakes and their associations with obesity and cardio-metabolic indicators in European adolescents: the HELENA cross-sectional study. Nutr J 14:10. doi:10.1186/1475-2891-14-10

46. Ulbak J, Lauritzen L, Hansen HS, Michaelsen KF (2004) Diet and blood pressure in 2.5-y-old Danish children. Am J Clin Nutr 79(6):1095-1102

47. Berenson GS, Blonde CV, Farris RP (1979) Cardiovascular disease risk factor variables during the first year of life. Am J Dis Child 133(10):1049-1057

48. Lucas A, Morley R (1994) Does early nutrition in infants born before term programme later blood pressure? Br Med J 309(6950):304-308

49. de Moraes AC, Bel-Serrat S, Manios Y, Molnar D, Kafatos A, Cuenca-Garcia M, Huybrechts I, Sette S, Widhalm K, Stehle P, Jimenez-Pavon D, Carvalho HB, Moreno LA (2015) Dietary protein and amino acids intake and its relationship with blood pressure in adolescents: the HELENA STUDY. Eur J Public Health. doi:10.1093/eurpub/cku233

50. Voortman T, Bakker H, Sedaghat S, Kiefte-de Jong JC, Hofman A, Jaddoe VW, Franco OH, van den Hooven EH (2015) Protein intake in infancy and kidney size and function at the age of 6 years: the Generation R Study. Pediatr Nephrol. doi:10.1007/ s00467-015-3096-4

51. Parks EJ, Krauss RM, Christiansen MP, Neese RA, Hellerstein MK (1999) Effects of a low-fat, high-carbohydrate diet on VLDL-triglyceride assembly, production, and clearance. J Clin Invest 104(8):1087-1096. doi:10.1172/JCI6572

52. Larsson SC, Virtamo J, Wolk A (2012) Dietary protein intake and risk of stroke in women. Atherosclerosis 224(1):247-251. doi:10.1016/j.atherosclerosis.2012.07.009 